\title{
Possible Actions in the Built Environment to Enhance Physical Activity: Systematic Review
}

\author{
Mina Safizadeh ${ }^{1}$, Massoomeh Hedayati Marzbali ${ }^{1}$, Aldrin Abdullah ${ }^{1} \&$ Nor Zarifah Maliki $^{1}$ \\ ${ }^{1}$ School of Housing, Building \& Planning, Universiti Sains Malaysia, Penang, Malaysia \\ Correspondence: Massoomeh Hedayati Marzbali, Senior Lecturer in Landscape Architecture, School of Housing, \\ Building \& Planning, Universiti Sains Malaysia, 11800 Penang, Malaysia. Tel: 60-17-447-1295. E-mail: \\ hedayati@usm.my
}

Received: July 22, 2020

Accepted: July 30, $2020 \quad$ Online Published: August 12, 2020

doi:10.5539/jsd.v13n5p1

URL: https://doi.org/10.5539/jsd.v13n5p1

\begin{abstract}
As a crucial factor of health, physical activity is widely explored in many empirical studies. The problem of how the built environment may affect physical activity attributes was discussed in previous studies, and the classification of interventions was presented in a limited scope. Therefore, the present study aims to review built environment interventions while classifying them into motivators and barriers of physical activity in residential neighbourhoods worldwide. Firstly, the main dimensions explaining how the built environment affects physical activity are presented. Fifteen papers published between 2009 and 2019 were identified by an extensive search in ScienceDirect, Web of Science, Scopus and PubMed. These works were systematically reviewed based on their main characteristics and then classified based on their relevant operationalisation of variables. Improving motivators and conquering barriers of physical activity on neighbourhoods lead to a healthy and sustainable society. The results of the current work can help policymakers and urban planners use exclusive methods for each part of neighbourhood planning and create an environment that overcomes barriers and promotes public physical activity levels.
\end{abstract}

Keywords: built environment, motivators and barriers, neighbourhood design, physical activity

\section{Introduction}

A growing body of evidence, including socio-ecological models, shows that an individual's health status is influenced by not only the person's behaviour but also by the interventions of surrounding built environment (Stokols, 1992). The built environment concept may have various dimensions and aspects, and it is defined as 'elements of the physical environment that are man-made, in contrast to the natural environment. The built environment includes everything from metropolitan land-use patterns to urban transportation systems to individual buildings and the spaces around them' (Anderson, 2009, p. 28). The effect of city environment features (including form, facilities and utilities) on public health began in the 19th century when the prevalence of contagious disease was described (Koohsari, Badland, \& Giles-Corti, 2013; Snow, 1855). Furthermore, 'urban planning can, and should, play a role in making the impact of urbanisation on health beneficial for people' (World Health Organization, 2011, p. 2). People's health status is not only affected by individual treatment but also by attributes of the surrounding area (Barton \& Grant, 2006; Stokols, 1992). Physical inactivity is a crucial contributor to global health, and it is related to the built environment. Determining the causes of physical activities is important to enhance and improve public health interventions (Sallis, Owen, \& Fotheringham, 2000). Approximately $31 \%$ of adults worldwide are physically inactive; $17 \%$ of adults in Southeast Asia are inactive and the figure rises to $43 \%$ in the eastern Mediterranean and in North and South America. Furthermore, inactivity increases with age, especially in women (Hallal et al., 2012). Public physical activity alteration by using current surveillance data is a crucial challenge in the 21 st century due to new trends in society that led to the reduction, not the enhancement, of physical activities (Hallal et al., 2012).

Physical activity may be affected by many environmental factors. Correlates of human physical activity and environmental factors were investigated in the last few years and categorised into social environment, built environment and natural environment factors (Bauman et al., 2012). Physical activity is defined as 'any bodily movement produced by skeletal muscle that results in energy expenditure' (Caspersen, Powell, \& Christenson, 1985, p. 126). Physical activity encompasses a broad range of activities, including walking, jogging, cycling, 
swimming, exercise and dancing. By contrast, it can be categorised by aims of recreation and utility (Frank, Engelke, Engelke, \& Schmid, 2003). Other categorisations include transport, recreational, professional and indoor activities, like household activities (Koohsari et al., 2013). Recreation from physical activity comprises activities undertaken for discretionary reasons in someone's leisure time', whereas utilitarian physical activities are 'those that are worked with daily habits' (Frank et al., 2003, p. 58). Features of the built environment can substantially affect physical activity, particularly that of urban populations, leading to issues in health and well-being (Bauman et al., 2012; Zapata-Diomedi, Herrera, \& Veerman, 2016). The major part of noncommunicable disease can directly and indirectly be attributed to the insufficiency of physical activity (Allender, Cavill, Parker, \& Foster, 2009). Evidence shows the links between the built environment and physical activity attributes from various perspectives (Abildso, Zizzi, Abildso, Steele, \& Gordon, 2007; Clarke, Ailshire, Bader, Morenoff, \& House, 2008; Kahn et al., 2002; Li, Fisher, Brownson, \& Bosworth, 2005; Saelens \& Handy, 2008; Schulz, Romppel, \& Grande, 2016; Wang, Chau, $\mathrm{Ng}$, \& Leung, 2016), including the infrastructure, aesthetic, street network design, safety, exercise facilities and density and intensity dimensions. In recent years, an increasing number of quantitative studies were conducted to fill the gap between the built environment interventions and public physical activities. Few reviews on the relationship between built environment and physical activity focused on a limited geographic scope area (Day, 2016; O. Ferdinand, Sen, Rahurkar, Engler, \& Menachemi, 2012), barriers (Wang et al., 2016) and older adults (Gharaveis, 2020; Moran et al., 2014); they also generally discussed the built environment and physical activity (Smith et al., 2017). However, the detailed distinction and classification of interventions into categories of motivators and barriers have not been presented yet. Thus, in the present study, we attempt to review a wide range of interventions focusing worldwide on neighbourhood areas with large sample sizes. The present study takes the following objectives:

1) to identify the association among built environment, physical activity and public health;

2) to describe the characteristics and methodologies of studies published in this field;

3) to classify the barriers and motivators of physical activity within the built environment;

4) to recognise how urban planners and decision-makers help create a built environment that is supportive of physical activity.

In the last few decades, continuous studies represented the different dimensions of the built environment influencing physical activity. As a result, several theories with numerous bodies of knowledge emerged to investigate the effects of the built environment on physical activity. Table 1 shows a categorised summary of major dimensions, based on respected indicators, explaining how the built environment may affect physical activity attributes. 
Table 1. Classification of diverse dimensions and indicators on the linkage of built environment and physical activity attributes

\begin{tabular}{|c|c|c|}
\hline Dimension & Indicators & Representatives \\
\hline Infrastructure & $\begin{array}{l}\text { - Access and close proximity to routine destinations } \\
\text { - Design of public spaces } \\
\text { - Diversity of land use } \\
\text { - Ability to provide recreational } \\
\text { - Neighbourhood upkeep condition }\end{array}$ & $\begin{array}{l}\text { (Wang, Chau, Ng, \& Leung, 2016) } \\
\text { (Schulz, Romppel, \& Grande, 2016) } \\
\text { (Piyapong, Riruengrong, Wipawee, } \\
\text { Siriphan, \& Passanan, 2019) }\end{array}$ \\
\hline Aesthetic qualities & $\begin{array}{l}\text { - Enjoyable scenery } \\
\text { - Arrangement of the physical elements }\end{array}$ & $\begin{array}{l}\text { (Abildso, Zizzi, Abildso, Steele, \& } \\
\text { Gordon, 2007) } \\
\text { (Saelens \& Handy, 2008) }\end{array}$ \\
\hline Street network design & $\begin{array}{l}\text { - Street connectivity } \\
\text { - Number of street intersections } \\
\text { - Traffic volumes }\end{array}$ & $\begin{array}{l}\text { (Li, Fisher, Brownson, \& Bosworth, } \\
\text { 2005) }\end{array}$ \\
\hline Safety & $\begin{array}{l}\text { - Residents' perceived safety } \\
\text { - Rate of crime } \\
\text { - Safe and lighted sidewalks and walking paths }\end{array}$ & $\begin{array}{l}\text { (Li et al., 2005) } \\
\text { (Clarke, Ailshire, Bader, Morenoff, \& } \\
\text { House, 2008) (Kahn et al., 2002) } \\
\text { (Badiora Adewumi \& Odufuwa } \\
\text { Bashir, 2019) }\end{array}$ \\
\hline Exercise facilities & $\begin{array}{l}\text { - Density and proximity of green spaces or parks } \\
\text { - Provision of signs, or encouragements for physical } \\
\text { activity }\end{array}$ & $\begin{array}{l}\text { (Bancroft et al., 2015) } \\
\text { (Kahn et al., 2002) } \\
\text { (Asefi \& Ghanbarpour Nosrati, 2020) }\end{array}$ \\
\hline Density and intensity & $\begin{array}{l}\text { - Amount of population, employment, or building square } \\
\text { in a given area }\end{array}$ & $\begin{array}{l}\text { (Handy, Boarnet, Ewing, \& } \\
\text { Killingsworth, 2002) }\end{array}$ \\
\hline
\end{tabular}

\section{Method}

\subsection{Literature Search}

Research objectives were addressed by conducting a comprehensive systematic review that focused narrowly on the recent literature that examines the most influencing barriers and motivators of the built environment concerning physical activity range. A systematic and extensive search was conducted in several electronic databases, including articles published from 2009 to 2019 following the PRISMA statement (Moher, Liberati, Tetzlaff, \& Altman, 2009). The literature search was conducted between November 2019 to January 2020, using the major databases, including Web of Science, Scopus, ScienceDirect and PubMed. The keywords 'physical activity', 'health', 'built environment', 'urban design', 'neighbourhood' and 'walking and cycling' were used.

\subsection{Literature Inclusion and Exclusion Criteria}

No limit was applied to the geographic location, and we attempted to include a worldwide domain. The selection process was conducted in two stages. The titles and abstracts were assessed, and then the whole text of selected articles was reviewed. A definition of inclusion criteria was conducted prior to the extensive search. The inclusion criteria for articles were as follows:

- published between 2009-2019

- published in peer-reviewed journals and written in English

- highly cited

- highest relevancy

- outcomes related to mortality, suicide, social inequity, mental health and maternal conditions were excluded 
- $\quad$ interconnection analysis and ability to answer research questions

Our search identified 21,548 records. After title screening, approximately 200 articles remained. Consequently, based on the abstract screening, 70 records were included. Finally, 15 records were selected for detailed analysis. Figure 1 shows the study search and selection process.

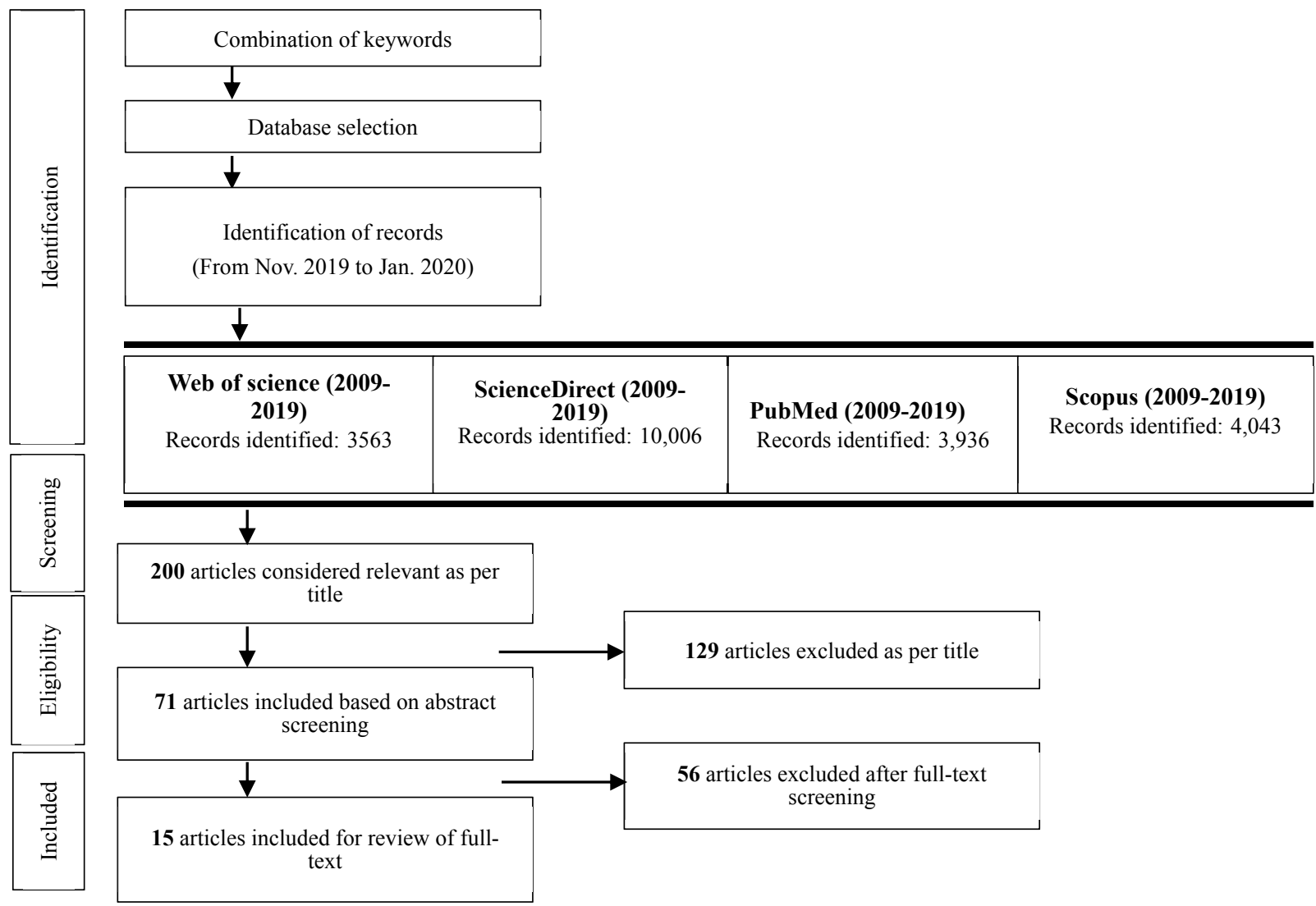

Figure 1. Flowchart of study search and selection process

After screening the full text of included articles, data extraction was systematically conducted, and the overview and main characteristics of each study were obtained. Data extraction was conducted initially by extracting the summary of the following study characteristics: study design, study location and population age, environmental intervention examined, method of physical activity measurement, major findings and recommendations. In the following section, a descriptive analysis of each research method and results is discussed, and the variables are categorised as the most important physical activity motivators or barriers by tabulating their frequencies.

\section{Results}

\subsection{General Characteristics}

The number of studies has clearly decreased during 2015-2019. Fifteen articles, highly relevant to the subject and published between 2009 and 2019, were included for detailed review. We attempted to cover all continents. The number of excluded studies and the exclusion reasons are illustrated in Figure 1. Four studies were conducted in the USA, followed by two - each in Australia and the UK; one each in Canada, New Zealand, China, Egypt, Scotland and Taiwan;. One study was multi-country, comprising 11 countries worldwide. Samples were large in terms of the participants and the geographical target. Most of the selected articles contained more than 1,000 $(\mathrm{n}=$ 9) samples, and four studies included more than 5,000 samples. The focus of seven studies was on vulnerable populations, including children, adolescents and older adults.

\subsection{Study Design}

Of the 15 studies, eight were cross-sectional. Four studies were longitudinal surveys, and only one used a mixedmethod approach. One study included a descriptive method, and one used case study. The data collection method in the majority of studies was questionnaire $(\mathrm{n}=6)$ or a mix of questionnaire and existing data from previous 
studies or databases $(n=3)$. Five studies also used existing data, and two studies used a combination of existing data and observations. Finally, only two articles conducted interviews. The majority of studies $(n=9)$ investigated selected regions or neighbourhoods. As shown in Table 2, four studies examined nationwide samples and two included international targets.

Table 2. Summary of the selected articles

\begin{tabular}{lclc}
\hline \multicolumn{1}{c}{ Characteristics } & No. of articles & \multicolumn{1}{c}{ Characteristics } & No. of articles \\
\hline Year of publication & & Data collection method & \\
$2009-2014$ & 6 & Questionnaire & 4 \\
$2015-2019$ & 9 & Questionnaire and existing data & 2 \\
Country & & Existing data & 5 \\
USA & 4 & Existing data and observation & 2 \\
Canada & 1 & Interview & 2 \\
Australia & 2 & Study design & \\
New Zealand & 1 & Cross-sectional & 8 \\
UK & 2 & Descriptive & 1 \\
China & 1 & Longitudinal & 4 \\
Egypt & 1 & Mixed mode & 1 \\
Scotland & 1 & Case study & 1 \\
Taiwan & 1 & Sample size & \\
Multi-country & 1 & $\mathrm{n}<100$ & 3 \\
Age group & & $100<\mathrm{n}<1000$ & 3 \\
Child & 1 & $1000<\mathrm{n}<5000$ & 5 \\
Adolescence & 1 & $\mathrm{n}>5000$ & 4 \\
Adults & 6 & Geographical target & \\
Older adults & 5 & Nation-wide & 4 \\
Not mentioned & 2 & Selected regions & 9 \\
& & International & 2 \\
\hline & & & \\
\hline & & &
\end{tabular}

\subsection{Physical Environmental Categories Identified in the Selected Studies}

Table 2 provides brief details on the 15 reviewed studies, including the study design, study location and population age, method of physical activity measurement, major findings on environmental factors and study recommendations if existing. The built environment measured factors in the selected studies were categorised based on the presented dimensions in Table 1. The six following categories extracted from the data are infrastructure, aesthetic qualities, street network design, safety, exercise facilities, density and intensity. Corresponding subcategories and environmental factors are explained in detail in Appendix 1.

\subsubsection{Infrastructure}

Infrastructural issues were subdivided into the following categories: (i) access and close proximity to routine destinations, (ii) design of public spaces, (iii) diversity of land use, (iv) ability to provide recreation and (v) neighbourhood upkeep condition. Most studies attempted to examine more than one environmental factor in relation to physical activity. The majority of reviewed studies addressed the association of the infrastructural subcategories and people's physical activity attributes $(n=13)$. A high range of land use diversity is associated with the chance to engage in physical activity particularly active transports (Tewahade et al., 2019). Local amenities and facilities are longitudinally related to chronic diseases, such as type 2 diabetes, because of their impacts on routine physical activity of people during the day (Dendup, Astell-Burt, \& Feng, 2019).

Neighbourhood walkability and sidewalk quality are closely related with physical activity that leads to a reduced prevalence of overweight and obesity (Carlson, Aytur, Gardner, \& Rogers, 2012; Creatore et al., 2016; King et al., 
2011). Accordingly, a pedestrian-friendly design in an urban context may decrease approximately $5.5 \%$ of annual deaths due to decreases in cases of CHD, hypertension, stroke and diabetes (Gibson et al., 2015). Biking infrastructures and traffic safety in built environment attributes are significantly high in the regions that residents have a lower body mass index (BMI) range (Algoday, Ayad, \& Saadallah, 2019; Sallis et al., 2009). Access to lowcost recreation facilities and locating transport stops with a short distance in the neighbourhood are highly related to meeting the guidelines of physical activity (Panter, Heinen, Mackett, \& Ogilvie, 2016; Sallis et al., 2009), particularly in older adults (Frank, Kerr, Rosenberg, \& King, 2010). The parents consider a direct association between the whole physical, social and upkeep conditions in the surrounding built environment and their children's health mediating physical activity (Teedon, Gillespie, Lindsay, \& Baker, 2014). Distribution of functional spaces such as coffee shops, stores and markets is also highly related to reaching the sufficient amount of physical activity (Creatore et al., 2016; Huang, Kung, \& Hu, 2018; Zhou, Grady, \& Chen, 2017).

\subsubsection{Aesthetic Qualities}

Aesthetic qualities, including subcategories of (i) enjoyable sceneries and (ii) arrangement of the physical elements, were identified in three studies. Elements in the built environment which are provided by urban design strategies should enhance the environment's visual pleasure. This environmental visual pleasure is associated with adults' weight status because of its impact on their physical activity (Algoday et al., 2019; Zhou et al., 2017). Physical elements arrangement factors may influence the parents to encourage their children to have physical activities independently (Teedon et al., 2014).

\subsubsection{Street Network Design}

Street network design was subdivided into (i) street connectivity, (ii) number of street intersections and (iii) traffic volumes. Nine studies examined this factor in relation to the amount of physical activities.

Street layouts and connectivity is a crucial indicator that encourages people to walk for transport (Koohsari, Oka, Owen, \& Sugiyama, 2019). Walkability of a neighbourhood has a direct relationship to the road connectivity and intersection density; thus, it affects obesity, overweight and accordingly disease like stroke and diabetes (Algoday et al., 2019; Creatore et al., 2016; Gibson et al., 2015).

Street connectivity within 1 kilometre from individuals' homes can affect walking levels of neighbourhood and older adults' physical activity (Frank et al., 2010). Traffic-free routes and properly connected sidewalks, roads and intersections associated active transport and moderate to vigorous physical activity (Carlson et al., 2012; King et al., 2011; Panter et al., 2016).

\subsubsection{Safety}

Safety included three subcategories, namely, (i) residents' perceived safety, (ii) rate of crime and (iii) safe and lighted sidewalks and walking paths. The safety characteristics of the built environment and the association with physical activity were addressed in three studies. Perceived day and night crime rates which create unsafe walking paths were closely related to higher odds of type 2 diabetes occurrence (Dendup et al., 2019). Safety at night which affects the resident's active transport positively impacts BMI (Algoday et al., 2019). However, only one study, conducted internationally in 11 countries, found that perceived crime rate was not related to physical activity prevalence (Sallis et al., 2009).

\subsubsection{Exercise Facilities}

Exercise facilities are divided into two subcategories, namely, (i) density and proximity of green spaces or parks and (ii) provision of signs or encouragements for physical activity. Five studies investigated the association between physical activity and exercise facilities. Park and green space density was positively correlated with active transportation and the recommended range of physical activity (Huang et al., 2018; Tewahade et al., 2019). By contrast, two of the five studies concluded that the number of park and green space density has no significant impact on residents' physical activity or their BMI, possibly because of the lack of services or encouraging signs and even security (Algoday et al., 2019; Creatore et al., 2016; Richardson, Pearce, Mitchell, \& Kingham, 2013). Creating park and green spaces with good provision of facilities is valued by parents for physical activity and health benefits in their children (Teedon et al., 2014).

\subsubsection{Density and Intensity}

Density and intensity consist of the number of population, employment, or building squares in a given area. Of the 15 studies, five examined the factor correlates of physical activity. Residence density was significantly associated with neighbourhood walkability and active transportation (Creatore et al., 2016; Tewahade et al., 2019). In one of the five relevant studies, which developed a computer simulation for neighbourhood features to promote walking, 
population density was introduced as a variable in functions that positively impact walkability (Gibson et al., 2015). Population density and retail density are some of the determinants of a neighbourhood that promotes active transport (Frank et al., 2010; King et al., 2011).

\section{Discussion}

In the review of the association between built environment and physical activity attributes, we included 15 studies that could be reviewed in detail and varied considerably in design and methodology. The following environmental categories significantly affected public physical activities: infrastructure, aesthetic qualities, street network design, safety, exercise facilities and density and intensity. The focus of the majority of studies was based on infrastructural issues. The infrastructural facilities should be in good condition to encourage physical activity in residents. For example, providing sidewalks without a good design or erecting a park without being concerned with toilets does not promote physical activity or walking outdoors. Aesthetic issues in urban design have not been thoroughly investigated though it is positively associated with people's outdoor physical activity. By contrast, the street design network substantially impacts public physical activity which can be examined more precisely due to current techniques, such as space syntax. As shown in Table 3, the investigated factors were classified into two main groups, namely, motivators and barriers of physical activities.

Table 3. Motivators and barriers of physical activity attributes associated with the built environment

\begin{tabular}{|c|c|}
\hline Physical activity & Corresponding factors \\
\hline \multirow[t]{13}{*}{ Motivators } & 1. Proportion of number of residential units to the neighbourhood area \\
\hline & 2. Number of retail outlets or any other businesses or services in area \\
\hline & $\begin{array}{l}\text { 3. Variety of types of land use per unit group (i.e. residential, office, shops, } \\
\text { entertainment and institutional) }\end{array}$ \\
\hline & 4. Population per neighbourhood area \\
\hline & 5. Walkable destinations \\
\hline & $\begin{array}{l}\text { 6. Greater street connectivity (i.e. the ratio of three-legged or greater intersections } \\
\text { divided by the neighbourhood area) }\end{array}$ \\
\hline & 7. Presence and quality of sidewalks \\
\hline & 8. Lighting of the walking paths \\
\hline & 9. Liveliness by population movements \\
\hline & 10. Streetscape form quality (i.e. street width and buildings height) \\
\hline & 11. Biking routes, parking and safety \\
\hline & 12. Visual pleasure (e.g. trees, façade designs and water and electricity elements) \\
\hline & $\begin{array}{l}\text { 13. Presence and condition of public or private recreational spaces (i.e. gyms, } \\
\text { playgrounds and workout elements in parks) }\end{array}$ \\
\hline \multirow[t]{4}{*}{ Barriers } & 1. Mean distance to nearest park and green spaces \\
\hline & 2. Distance to functional spaces \\
\hline & 3. Distance to transport stations \\
\hline & 4. Day and night crime rate \\
\hline
\end{tabular}

\section{Conclusion}

The investigation of built environment factors affecting physical activity attributes is becoming increasingly important in recent years. Few review studies were conducted on the relationship between the built environment and physical activity. However, the detailed distinction and classification of interventions into categories of motivators and barriers have not been presented yet. In this study, firstly, a categorised summary of major dimensions explaining how the built environment may affect physical activity was presented. A wide range of interventions was then reviewed, focusing on neighbourhood areas worldwide with large sample sizes. In this 
review, 15 papers published between 2009 and 2019 were examined in detail. In conclusion, this review provided a detailed classification of built environment characteristics in every relevant dimension that led to increase physical activity and accordingly public health. Motivators and barriers were also mentioned.

Findings showed that the proportion of number of residential units to the neighbourhood area, variety of types of land use per unit group (i.e. residential, office, shops, entertainment and institutional), population per neighbourhood area, lighting in the walking paths, liveliness by population movements, streetscape form quality (i.e. street width and building height), biking routes, parking and safety, visual pleasure (e.g. trees, façade designs and water and electricity elements) and presence and condition of public or private recreational spaces (i.e. gyms, playgrounds and workout elements in parks) are the most influencing motivators in neighbourhoods, encouraging residents to take part in physical activities. By contrast, mean distance to the nearest park and green spaces, distance to functional spaces, distance to transport stations and day and night crime rate are the factors that play a barrier role for physical activity in residents.

The primary strength of this review is the comprehensive search in numerous databases that reflected the subject. Another particular strength of this study is the global scope and the large samples covered by this review. These strengths assist designers and planners worldwide in making decisions. Furthermore, the level of detailed interventions classification in motivator and barrier types can facilitate the process of urban design. Nonetheless, limitations in the present study should be acknowledged. This study was a review of a limited number of studies in a limited time period. However, other factors related to the built environment, such as climate and gender, were not examined. The number of qualitative studies and studies that examined children was small. Furthermore, different types of physical activity were not categorised because some of the selected studies did not precisely define physical activity. Accordingly, future studies should consider factors like local climate and gender. Additional studies should be conducted on children below 15, and the definition and classification of physical activity should also be provided for consideration during data collection.

\section{Acknowledgments}

The authors would like to thank Universiti Sains Malaysia for financially supporting this research under Research University Grant (RUI, NO. 1001/PPBGN/8016079).

\section{References}

Abildso, C. G., Zizzi, S., Abildso, L. C., Steele, J. C., \& Gordon, P. M. (2007). Built environment and psychosocial factors associated with trail proximity and use. American Journal of Health Behavior, 31(4), 374-383. https://doi.org/10.5993/AJHB.31.4.4

Algoday, A., Ayad, H., \& Saadallah, D. (2019). Investigating the relationship between attributes of the built environment and adult obesity in Alexandria, Egypt. Alexandria Engineering Journal, 58(3), 1089-1097. https://doi.org/10.1016/j.aej.2019.09.011

Allender, S., Cavill, N., Parker, M., \& Foster, C. (2009). 'Tell us something we don't already know or do!'-The response of planning and transport professionals to public health guidance on the built environment and physical activity. Journal of public health policy, 30(1), 102-116. https://doi.org/10.1057/jphp.2008.43

Anderson, J. (2009). Interventions on diet and physical activity: what works: summary report: World Health Organization.

Asefi, A., \& Ghanbarpour Nosrati, A. (2020). The spatial justice in the distribution of built outdoor sports facilities. Journal of Facilities Management, 18(2), 159-178. https://doi.org/10.1108/JFM-09-2019-0051

Badiora Adewumi, I., \& Odufuwa Bashir, O. (2019). Fear dynamics in public places: a case study of urban shopping centers. Journal of Place Management and Development, 12(2), 248-270. https://doi.org/10.1108/JPMD-11-2018-0084

Bancroft, C., Joshi, S., Rundle, A., Hutson, M., Chong, C., Weiss, C. C., ... Lovasi, G. (2015). Association of proximity and density of parks and objectively measured physical activity in the United States: A systematic review. Social Science \& Medicine, 138, 22-30. https://doi.org/10.1016/j.socscimed.2015.05.034

Barton, H., \& Grant, M. (2006). A health map for the local human habitat. The journal for the royal society for the promotion of health, 126(6), 252-253. https://doi.org/10.1177/1466424006070466

Bauman, A. E., Reis, R. S., Sallis, J. F., Wells, J. C., Loos, R. J., Martin, B. W., \& Group, L. P. A. S. W. (2012). Correlates of physical activity: why are some people physically active and others not? The lancet, 380(9838), 258-271. https://doi.org/10.1016/S0140-6736(12)60735-1 
Carlson, C., Aytur, S., Gardner, K., \& Rogers, S. (2012). Complexity in built environment, health, and destination walking: a neighborhood-scale analysis. Journal of urban health, 89(2), 270-284. https://doi.org/10.1007/s11524-011-9652-8

Caspersen, C. J., Powell, K. E., \& Christenson, G. M. (1985). Physical activity, exercise, and physical fitness: definitions and distinctions for health-related research. Public health rep, 100(2), 126-131.

Clarke, P., Ailshire, J. A., Bader, M., Morenoff, J. D., \& House, J. S. (2008). Mobility disability and the urban built environment. American journal of epidemiology, 168(5), 506-513. https://doi.org/10.1093/aje/kwn185

Creatore, M. I., Glazier, R. H., Moineddin, R., Fazli, G. S., Johns, A., Gozdyra, P., ... Booth, G. L. (2016). Association of Neighborhood Walkability With Change in Overweight, Obesity, and Diabetes. Jama-Journal of the American Medical Association, 315(20), 2211-2220. https://doi.org/10.1001/jama.2016.5898

Day, K. (2016). Built environmental correlates of physical activity in China: A review. Preventive medicine reports, 3, 303-316. https://doi.org/10.1016/j.pmedr.2016.03.007

Dendup, T., Astell-Burt, T., \& Feng, X. (2019). Residential self-selection, perceived built environment and type 2 diabetes incidence: A longitudinal analysis of 36,224 middle to older age adults. Health \& place, 58, 102154. https://doi.org/10.1016/j.healthplace.2019.102154

Frank, L., Engelke, P., Engelke, S. F. P., \& Schmid, T. (2003). Health and community design: The impact of the built environment on physical activity. Island Press.

Frank, L., Kerr, J., Rosenberg, D., \& King, A. (2010). Healthy aging and where you live: community design relationships with physical activity and body weight in older Americans. Journal of physical activity and health, 7(s1), S82-S90. https://doi.org/10.1123/jpah.7.s1.s82

Gharaveis, A. (2020). A systematic framework for understanding environmental design influences on physical activity in the elderly population. Facilities. https://doi.org/10.1108/F-08-2018-0094

Gibson, J. M., Rodriguez, D., Dennerlein, T., Mead, J., Hasch, T., Meacci, G., \& Levin, S. (2015). Predicting urban design effects on physical activity and public health: a case study. Health \& place, 35, 79-84. https://doi.org/10.1016/j.healthplace.2015.07.005

Hallal, P. C., Andersen, L. B., Bull, F. C., Guthold, R., Haskell, W., Ekelund, U., \& Group, L. P. A. S. W. (2012). Global physical activity levels: surveillance progress, pitfalls, and prospects. The lancet, 380(9838), 247-257. https://doi.org/10.1016/S0140-6736(12)60646-1

Huang, N.-C., Kung, S.-F., \& Hu, S. (2018). The relationship between urbanization, the built environment, and physical activity among older adults in Taiwan. International journal of environmental research and public health, 15(5), 836. https://doi.org/10.3390/ijerph15050836

Kahn, E. B., Ramsey, L. T., Brownson, R. C., Heath, G. W., Howze, E. H., Powell, K. E., ... Corso, P. (2002). The effectiveness of interventions to increase physical activity: a systematic review. American journal of preventive medicine, 22(4), 73-107. https://doi.org/10.1016/S0749-3797(02)00434-8

King, A. C., Sallis, J. F., Frank, L. D., Saelens, B. E., Cain, K., Conway, T. L., ... Kerr, J. (2011). Aging in neighborhoods differing in walkability and income: associations with physical activity and obesity in older adults. Social Science \& Medicine, 73(10), 1525-1533. https://doi.org/10.1016/j.socscimed.2011.08.032

Koohsari, M. J., Badland, H., \& Giles-Corti, B. (2013). (Re) Designing the built environment to support physical activity: Bringing public health back into urban design and planning. Cities, 35, 294-298. https://doi.org/10.1016/j.cities.2013.07.001

Koohsari, M. J., Oka, K., Owen, N., \& Sugiyama, T. (2019). Natural movement: A space syntax theory linking urban form and function with walking for transport. Health \& place. https://doi.org/10.1016/j.healthplace.2019.01.002

Li, F., Fisher, K. J., Brownson, R. C., \& Bosworth, M. (2005). Multilevel modelling of built environment characteristics related to neighbourhood walking activity in older adults. Journal of Epidemiology \& Community Health, 59(7), 558-564. https://doi.org/10.1136/jech.2004.028399

Moher, D., Liberati, A., Tetzlaff, J., \& Altman, D. G. (2009). Preferred reporting items for systematic reviews and meta-analyses: the PRISMA statement. Annals of internal medicine, 151(4), 264-269. https://doi.org/10.7326/0003-4819-151-4-200908180-00135 
Moran, M., Van Cauwenberg, J., Hercky-Linnewiel, R., Cerin, E., Deforche, B., \& Plaut, P. (2014). Understanding the relationships between the physical environment and physical activity in older adults: a systematic review of qualitative studies. International Journal of Behavioral Nutrition and Physical Activity, 11(1), 79. https://doi.org/10.7326/0003-4819-151-4-200908180-00135

O. Ferdinand, A., Sen, B., Rahurkar, S., Engler, S., \& Menachemi, N. (2012). The relationship between built environments and physical activity: a systematic review. American journal of public health, 102(10), e7-e13. https://doi.org/10.2105/AJPH.2012.300740

Organization, W. H. (2011). Healthy urban planning: Report of a consultation meeting. Kobe: Centre for Health Development. World Health Organization.

Panter, J., Heinen, E., Mackett, R., \& Ogilvie, D. (2016). Impact of new transport infrastructure on walking, cycling, and physical activity. American journal of preventive medicine, 50(2), e45-e53. https://doi.org/10.1016/j.amepre.2015.09.021

Richardson, E. A., Pearce, J., Mitchell, R., \& Kingham, S. (2013). Role of physical activity in the relationship between urban green space and health. Public health, 127(4), 318-324. https://doi.org/10.1016/j.puhe.2013.01.004

Saelens, B. E., \& Handy, S. L. (2008). Built environment correlates of walking: a review. Medicine and science in sports and exercise, 40(7 Suppl), S550-S566. https://doi.org/10.1249/MSS.0b013e31817c67a4

Sallis, J. F., Bowles, H. R., Bauman, A., Ainsworth, B. E., Bull, F. C., Craig, C. L., ... Matsudo, V. (2009). Neighborhood environments and physical activity among adults in 11 countries. American journal of preventive medicine, 36(6), 484-490. https://doi.org/10.1016/j.amepre.2009.01.031

Sallis, J. F., Owen, N., \& Fotheringham, M. J. (2000). Behavioral epidemiology: a systematic framework to classify phases of research on health promotion and disease prevention. Annals of behavioral medicine, 22(4), 294-298. https://doi.org/10.1007/BF02895665

Schulz, M., Romppel, M., \& Grande, G. (2016). Built environment and health: a systematic review of studies in Germany. Journal of Public Health, 40(1), 8-15. https://doi.org/10.1093/pubmed/fdw141

Smith, M., Hosking, J., Woodward, A., Witten, K., MacMillan, A., Field, A., ... Mackie, H. (2017). Systematic literature review of built environment effects on physical activity and active transport - an update and new findings on health equity. International Journal of Behavioral Nutrition and Physical Activity, 14, 27. https://doi.org/10.1186/s12966-017-0613-9

Snow, J. (1855). On the mode of communication of cholera. John Churchill.

Stokols, D. (1992). Establishing and maintaining healthy environments: toward a social ecology of health promotion. American psychologist, 47(1), 6. https://doi.org/10.1037/0003-066X.47.1.6

Teedon, P., Gillespie, M., Lindsay, K., \& Baker, K. (2014). Parental perceptions of the impacts the built environment has on young children' s health: a qualitative examination and lay assessment amongst residents in four Scottish communities. Health \& place, 28, 50-57. https://doi.org/10.1016/j.healthplace.2014.03.010

Tewahade, S., Li, K., Goldstein, R. B., Haynie, D., Iannotti, R. J., \& Simons-Morton, B. (2019). Association between the built environment and active transportation among U.S. adolescents. Journal of transport and health, 15. https://doi.org/10.1016/j.jth.2019.100629

Wang, Y., Chau, C., Ng, W., \& Leung, T. (2016). A review on the effects of physical built environment attributes on enhancing walking and cycling activity levels within residential neighborhoods. Cities, 50, 1-15. https://doi.org/10.1016/j.cities.2015.08.004

Zapata-Diomedi, B., Herrera, A. M. M., \& Veerman, J. L. (2016). The effects of built environment attributes on physical activity-related health and health care costs outcomes in Australia. Health \& place, 42, 19-29. https://doi.org/10.1016/j.healthplace.2016.08.010

Zhou, P., Grady, S. C., \& Chen, G. (2017). How the built environment affects change in older people's physical activity: A mixed-methods approach using longitudinal health survey data in urban China. Social Science \& Medicine, 192, 74-84. https://doi.org/10.1016/j.socscimed.2017.09.032 


\section{Appendix}

Detailed analysis of 15 included studies

\begin{tabular}{|c|c|c|c|c|c|c|}
\hline $\begin{array}{l}\text { Author(s) } \\
\text { and year }\end{array}$ & Study design & $\begin{array}{l}\text { Study location } \\
\text { and population } \\
\text { age }\end{array}$ & $\begin{array}{l}\text { Environmental } \\
\text { intervention } \\
\text { examined }\end{array}$ & $\begin{array}{l}\text { Method of } \\
\text { physical activity } \\
\text { measurement }\end{array}$ & Major findings & Recommendation \\
\hline $\begin{array}{l}\text { (Sallis et al., } \\
\text { 2009) }\end{array}$ & $\begin{array}{l}\text { Cross-sectional; } \\
\text { Questionnaire for } \\
\text { both } \\
\text { environmental } \\
\text { attributes and } \\
\text { physical activity. }\end{array}$ & $\begin{array}{l}11 \text { countries } \\
\text { including } \\
\text { Belgium, Brazil, } \\
\text { Canada, } \\
\text { Colombia, China } \\
\text { (Hong Kong), } \\
\text { Japan, Lithuania, } \\
\text { New Zealand, } \\
\text { Norway, Sweden, } \\
\text { and the U.S.; } \\
\text { N=11,541 adults } \\
\text { 18-65 years. }\end{array}$ & $\begin{array}{lr}\begin{array}{l}\text { Housing } \\
\text { shops }\end{array} & \begin{array}{r}\text { type, } \\
\text { density }\end{array} \\
\text { within } & \text { walking } \\
\text { distance, } & \text { transit } \\
\text { stop } & (10-15 \\
\text { minutes distance } \\
\text { from } \quad \text { home }), \\
\text { sidewalks, biking } \\
\text { facilities, low-cost } \\
\text { recreation } \\
\text { facilities, } \\
\text { crime rate at night }\end{array}$ & $\begin{array}{l}\text { International } \\
\text { Physical Activity } \\
\text { Questionnaire } \\
\text { (IPAQ) }\end{array}$ & $\begin{array}{l}\text { Five out of seven } \\
\text { interventions } \\
\text { (except house type } \\
\text { and perceived } \\
\text { crime) significantly } \\
\text { correlated meeting } \\
\text { physical activity } \\
\text { guidelines. }\end{array}$ & $\begin{array}{l}\text { The study } \\
\text { generalized the } \\
\text { previous studies } \\
\text { findings, conducted } \\
\text { in some developing } \\
\text { countries, correlating } \\
\text { built environments } \\
\text { and physical activity } \\
\text { to a wide range of } \\
\text { countries. Designing } \\
\text { the neighbourhood } \\
\text { which supports } \\
\text { physical activity } \\
\text { should be considered } \\
\text { as a worldwide health } \\
\text { issue. }\end{array}$ \\
\hline $\begin{array}{l}\text { (Frank et } \\
\text { al., 2010) }\end{array}$ & $\begin{array}{l}\text { Cross-sectional; } \\
\text { Existing data of a } \\
\text { previous study. }\end{array}$ & $\begin{array}{l}\text { U.S. and Atlanta; } \\
\mathrm{N}=1970 \text { adults } \\
\text { aged } 65 \text { years or } \\
\text { older. }\end{array}$ & $\begin{array}{l}\text { Street } \\
\text { connectivity, land } \\
\text { use mix, and } \\
\text { residential density } \\
\text { within a kilometre } \\
\text { from each } \\
\text { participant's } \\
\text { house. }\end{array}$ & Self-reported & $\begin{array}{l}\text { Walking levels can } \\
\text { increase if there are } \\
\text { accessible } \\
\text { destinations in a } \\
\text { short distance and } \\
\text { walkable } \\
\text { neighbourhoods. }\end{array}$ & $\begin{array}{l}\text { Financial incentives } \\
\text { to consider the } \\
\text { location of, and build } \\
\text { functional spaces } \\
\text { such as senior } \\
\text { centres, social } \\
\text { services, or medical } \\
\text { facilities in a } \\
\text { neighbourhood. }\end{array}$ \\
\hline $\begin{array}{l}\text { (King et al., } \\
\text { 2011) }\end{array}$ & $\begin{array}{l}\text { Cross-sectional; } \\
\text { CHAMPS } \\
\text { physical activity } \\
\text { questionnaire. }\end{array}$ & $\begin{array}{l}\text { U.S. (Seattle- } \\
\text { King County, } \\
\text { Washington and } \\
\text { Baltimore- } \\
\text { Washington DC } \\
\text { regions); } \\
\mathrm{N}=719 \text { Adults } \\
\text { aged } 66 \text { years and } \\
\text { older. }\end{array}$ & $\begin{array}{l}\text { Residential } \\
\text { density, retail floor } \\
\text { area ratio, land-use } \\
\text { mix, intersection } \\
\text { density. }\end{array}$ & $\begin{array}{l}\text { Accelerometer } \\
\text { measured } \\
\text { physical activity }\end{array}$ & $\begin{array}{l}\text { Neighbourhoods } \\
\text { were associated } \\
\text { with more active } \\
\text { transport and lower } \\
\text { body weight } \\
\text { irrespective of } \\
\text { neighbourhood } \\
\text { income and moving } \\
\text { disability levels. }\end{array}$ & $\begin{array}{l}\text { There should be } \\
\text { alarms from the } \\
\text { public health } \\
\text { organizations for the } \\
\text { enhancement of } \\
\text { those environmental } \\
\text { features that can } \\
\text { support physical } \\
\text { activity and healthy } \\
\text { aging. }\end{array}$ \\
\hline $\begin{array}{l}\text { (Carlson et } \\
\text { al., 2012) }\end{array}$ & $\begin{array}{l}\text { Cross-sectional; } \\
\text { Leyden Ireland } \\
\text { survey \& BRFSS } \\
\text { health questions; } \\
\text { Paper-copy } \\
\text { surveys door-to- } \\
\text { door. }\end{array}$ & $\begin{array}{l}\text { U.K. } \\
\text { (Manchester, } \\
\text { Portsmouth and } \\
\text { New Hampshire); } \\
\mathrm{N}=679 \text { in } 24 \\
\text { neighbourhoods. }\end{array}$ & $\begin{array}{l}\text { Presence and } \\
\text { quality } \\
\text { sidewalks, street } \\
\text { connectivity, } \\
\text { proximity to } \\
\text { services, road } \\
\text { lane-miles, and lot } \\
\text { size. }\end{array}$ & Self-reported & $\begin{array}{l}\text { The strongest } \\
\text { correlation of } \\
\text { destination walking } \\
\text { were found for } \\
\text { sidewalks and } \\
\text { connectivity. }\end{array}$ & $\begin{array}{l}\text { Altering strategies to } \\
\text { support capitalising } \\
\text { on important effects } \\
\text { to promote } \\
\text { walkability of } \\
\text { neighbourhoods. } \\
\text { Besides, examining } \\
\text { the built environment } \\
\text { changes which can } \\
\text { impact on physical } \\
\text { activity and health. }\end{array}$ \\
\hline $\begin{array}{l}\text { (Richardson } \\
\text { et al., 2013) }\end{array}$ & $\begin{array}{l}\text { Cross-sectional; } \\
\text { Used existing } \\
\text { data including the } \\
\text { analysis of } \\
\text { anonymized } \\
\text { individual health } \\
\text { survey responses. }\end{array}$ & $\begin{array}{l}\text { New Zealand } \\
\text { Nationwide; } \\
\mathrm{N}=\quad 8157 \\
\text { among }>15 \text { years } \\
\text { of age. }\end{array}$ & $\begin{array}{l}\text { Neighbourhood- } \\
\text { level green space } \\
\text { availability. }\end{array}$ & Self-reported & $\begin{array}{l}\text { Overall physical } \\
\text { activity levels were } \\
\text { higher in greener } \\
\text { neighbourhood } \\
\text { residents. }\end{array}$ & $\begin{array}{l}\text { Greener } \\
\text { neighbourhoods are } \\
\text { likely to be effective } \\
\text { for public physical } \\
\text { activity and health. }\end{array}$ \\
\hline
\end{tabular}




\begin{tabular}{|c|c|c|c|c|c|c|}
\hline $\begin{array}{l}\text { Author(s) } \\
\text { and year }\end{array}$ & Study design & $\begin{array}{l}\text { Study location } \\
\text { and population } \\
\text { age }\end{array}$ & $\begin{array}{l}\text { Environmental } \\
\text { intervention } \\
\text { examined }\end{array}$ & $\begin{array}{l}\text { Method of } \\
\text { physical activity } \\
\text { measurement }\end{array}$ & Major findings & Recommendation \\
\hline $\begin{array}{l}\text { (Teedon et } \\
\text { al., 2014) }\end{array}$ & $\begin{array}{l}\text { Cross-sectional; } \\
\text { Qualitative } \\
\text { examination } \\
\text { through } \\
\text { neighbourhood- } \\
\text { based } \\
\text { conversations and } \\
\text { workshop } \\
\text { interaction. }\end{array}$ & $\begin{array}{l}\text { Scotland } \\
\text { Nationwide; } \\
\mathrm{N}=85 \text { parents of } \\
\text { children aged } \\
\text { under nine and } \\
\text { age of parents } \\
<34 \text { years. }\end{array}$ & $\begin{array}{l}\text { Local community, } \\
\text { public and green } \\
\text { space, housing, } \\
\text { and service } \\
\text { provision. }\end{array}$ & $\begin{array}{l}\text { Reported } \\
\text { parents }\end{array}$ & $\begin{array}{l}\text { Parents reported } \\
\text { significant relations } \\
\text { with the } \\
\text { environment where } \\
\text { they live, and both } \\
\text { physical and social } \\
\text { activities of their } \\
\text { children. }\end{array}$ & $\begin{array}{l}\text { There should be } \\
\text { agendas to create and } \\
\text { promote more } \\
\text { sustainable } \\
\text { behaviours at a local } \\
\text { level including } \\
\text { housing strategies } \\
\text { and environmental } \\
\text { design. }\end{array}$ \\
\hline $\begin{array}{l}\text { (Gibson et } \\
\text { al., 2015) }\end{array}$ & $\begin{array}{l}\text { Case study; Used } \\
\text { existing data to } \\
\text { create a computer } \\
\text { simulation model. }\end{array}$ & $\begin{array}{l}\text { U.S. (North } \\
\text { California); } \\
\mathrm{N}=1200 \text { residents } \\
\text { of Raleigh's } \\
\text { BRRC } \\
\text { neighbourhood. }\end{array}$ & $\begin{array}{l}\text { Different urban } \\
\text { designs including } \\
\text { intersection } \\
\text { density, land-use } \\
\text { mix, residential } \\
\text { density and retail } \\
\text { floor area. }\end{array}$ & $\begin{array}{l}\text { Current walking } \\
\text { time by mailed } \\
\text { questionnaire; } \\
\text { Simulate changes } \\
\text { in transportation } \\
\text { by computing } \\
\text { formulas. }\end{array}$ & $\begin{array}{l}\text { Pedestrian-friendly } \\
\text { neighbourhoods } \\
\text { can cause reduction } \\
\text { of deaths occurred } \\
\text { because of stroke, } \\
\mathrm{CDH} \text {, diabetes and } \\
\text { hypertension. }\end{array}$ & $\begin{array}{l}\text { Constructing more } \\
\text { sidewalks throughout } \\
\text { the neighbourhoods. }\end{array}$ \\
\hline $\begin{array}{l}\text { (Creatore et } \\
\text { al., 2016) }\end{array}$ & $\begin{array}{l}\text { Longitudinal; } \\
\text { Used existing } \\
\text { data from national } \\
\text { databases; } \\
\text { Observation } \\
\text { method for } \\
\text { environmental } \\
\text { measures. }\end{array}$ & $\begin{array}{l}\text { Canada } \\
\text { (Southern } \\
\text { Ontario cities); } \\
\mathrm{N}=8777 \\
\text { neighbourhoods } \\
\text { about } 4 \text { million } \\
\text { adults, age 30-64 } \\
\text { years. }\end{array}$ & $\begin{array}{l}\text { Neighbourhood } \\
\text { walkability } \\
\text { (population } \\
\text { density, residential } \\
\text { density, walkable } \\
\text { destinations, street } \\
\text { connectivity, } \\
\text { access to local } \\
\text { parks, gyms and } \\
\text { coffee shops) }\end{array}$ & $\begin{array}{l}\text { Data collected } \\
\text { from national } \\
\text { databases. }\end{array}$ & $\begin{array}{l}\text { Neighbourhood } \\
\text { higher walkability } \\
\text { has a significant } \\
\text { association with the } \\
\text { reduction in the } \\
\text { prevalence of } \\
\text { obesity and } \\
\text { diabetes. }\end{array}$ & - \\
\hline $\begin{array}{l}\text { (Panter et } \\
\text { al., 2016) }\end{array}$ & $\begin{array}{l}\text { Longitudinal; } \\
\text { Used existing } \\
\text { data. }\end{array}$ & 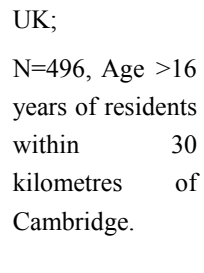 & $\begin{array}{l}\text { Exposure to the } \\
\text { new bus network. }\end{array}$ & $\begin{array}{l}\text { Recent Physical } \\
\text { Activity } \\
\text { Questionnaire } \\
\text { (RPAQ) }\end{array}$ & $\begin{array}{l}\text { Provision of new } \\
\text { transport } \\
\text { infrastructure } \\
\text { associated with } \\
\text { promoting active } \\
\text { commuting, } \\
\text { particularly biking. }\end{array}$ & $\begin{array}{l}\text { Supporting the } \\
\text { reconfiguration of } \\
\text { transport systems as a } \\
\text { part of policies to } \\
\text { improve public } \\
\text { health. }\end{array}$ \\
\hline $\begin{array}{l}\text { (Zhou et al., } \\
\text { 2017) }\end{array}$ & $\begin{array}{l}\text { Mixed mode; In } \\
\text { qualitative phase, } \\
\text { older adults were } \\
\text { interviewed about } \\
\text { their PA; In } \\
\text { quantitative } \\
\text { phase, data } \\
\text { obtained from } \\
\text { health survey } \\
\text { dataset of the } \\
\text { local hospitals. }\end{array}$ & $\begin{array}{l}\text { China } \\
\text { neighbourhoods } \\
\text { in Huainan, a } \\
\text { mid-sized city in } \\
\text { Anhui); } \\
\text { Adults age } 55+ \\
\text { years; } \\
\text { Qualitative phase } \\
\text { (N= 42) and } \\
\text { quantitative } \\
\text { phase }(\mathrm{N}=3094) .\end{array}$ & $\begin{array}{l}\text { Liveliness of an } \\
\text { apartment site and } \\
\text { the closeness of an } \\
\text { apartment site to } \\
\text { functional spaces. }\end{array}$ & $\begin{array}{l}\text { Physical activity } \\
\text { was measured as } \\
\text { the frequency of } \\
\text { PA per week, the } \\
\text { length of time } \\
\text { participating in } \\
\text { each activity, and } \\
\text { the intensity of } \\
\text { each activity } \\
\text { during the year. }\end{array}$ & $\begin{array}{l}\text { Liveliness of the } \\
\text { neighbourhood or } \\
\text { the apartment site } \\
\text { and the closeness of } \\
\text { the houses to } \\
\text { functional spaces } \\
\text { can encourage } \\
\text { sedentary older } \\
\text { people to have } \\
\text { physical activity. }\end{array}$ & $\begin{array}{l}\text { Assist older adults to } \\
\text { choose their houses } \\
\text { after their retirement, } \\
\text { close to functional } \\
\text { places. On the other } \\
\text { side, investments in } \\
\text { infrastructures and } \\
\text { urban planning } \\
\text { would increase the } \\
\text { accessibility of } \\
\text { functional spaces. }\end{array}$ \\
\hline $\begin{array}{l}\text { (Huang et } \\
\text { al., 2018) }\end{array}$ & $\begin{array}{l}\text { Cross-sectional; } \\
\text { Individual Level } \\
\text { used NHIS } \\
\text { dataset; } \\
\text { Ecological Level } \\
\text { used data of } \\
\text { National land-use } \\
\text { dataset. }\end{array}$ & $\begin{array}{l}\text { Taiwan } \\
\text { Nationwide; } \\
\mathrm{N}=2214, \quad \text { Age } \\
+65 \text { years }\end{array}$ & $\begin{array}{l}\text { Parks, greeneries, } \\
\text { squares, } \\
\text { playgrounds and } \\
\text { sport venues, and } \\
\text { schools which are } \\
\text { often used for } \\
\text { physical activities. }\end{array}$ & $\begin{array}{l}\text { Physical activity } \\
\text { (minutes/week) } \\
\text { was calculated } \\
\text { based on self- } \\
\text { report using } \\
\text { questionnaire. }\end{array}$ & $\begin{array}{l}\text { Township median } \\
\text { income, } \\
\text { urbanisation, and } \\
\text { the built } \\
\text { environment were } \\
\text { positively } \\
\text { associated with the } \\
\text { older adults' } \\
\text { physical activity. } \\
\text { The mentioned } \\
\text { association still }\end{array}$ & $\begin{array}{l}\text { To older adults take } \\
\text { part in physical } \\
\text { activities, } \\
\text { governments, urban } \\
\text { decision-makers, and } \\
\text { designers had better } \\
\text { identify and analyse } \\
\text { the obstacles and } \\
\text { advantages of the } \\
\text { built environment } \\
\text { characteristics in }\end{array}$ \\
\hline
\end{tabular}




\begin{tabular}{|c|c|c|c|c|c|c|}
\hline $\begin{array}{l}\text { Author(s) } \\
\text { and year }\end{array}$ & Study design & $\begin{array}{l}\text { Study location } \\
\text { and population } \\
\text { age }\end{array}$ & $\begin{array}{l}\text { Environmental } \\
\text { intervention } \\
\text { examined }\end{array}$ & $\begin{array}{l}\text { Method of } \\
\text { physical activity } \\
\text { measurement }\end{array}$ & Major findings & Recommendation \\
\hline & & & & & $\begin{array}{l}\text { existed after } \\
\text { individual-level } \\
\text { factors controlling. }\end{array}$ & $\begin{array}{l}\text { different urbanisation } \\
\text { levels. }\end{array}$ \\
\hline $\begin{array}{l}\text { (Algoday et } \\
\text { al., 2019) }\end{array}$ & $\begin{array}{l}\text { Cross-sectional; } \\
\text { Onsite } \\
\text { questionnaire. }\end{array}$ & $\begin{array}{l}\text { Egypt } \\
\text { (Alexandria); } \\
\mathrm{N}=309 \text {, Adults } \\
\text { 18-55 years old, } \\
\text { Two street } \\
\text { neighbourhoods, } \\
91 \quad \text { segments. }\end{array}$ & $\begin{array}{l}\text { Connectivity, } \\
\text { aesthetics, } \\
\text { pedestrian } \\
\text { amenities, bike } \\
\text { Infrastructure and } \\
\text { traffic safety. }\end{array}$ & $\begin{array}{l}\text { Self-reported } \\
\text { using onsite } \\
\text { questionnaire } \\
\text { concerning } \\
\text { preferred modes } \\
\text { of transportation. }\end{array}$ & $\begin{array}{l}\text { Built environment } \\
\text { attributes including } \\
\text { urban determinants } \\
\text { related to } \\
\text { connectivity, traffic } \\
\text { safety, aesthetics, } \\
\text { and form were } \\
\text { significantly higher } \\
\text { in the } \\
\text { neighbourhood } \\
\text { with residents } \\
\text { having lower BMI. }\end{array}$ & $\begin{array}{l}\text { Urban design need to } \\
\text { enhance more } \\
\text { walkable and safe } \\
\text { environments to take } \\
\text { part in tackling } \\
\text { obesity. }\end{array}$ \\
\hline $\begin{array}{l}\text { (Dendup et } \\
\text { al., 2019) }\end{array}$ & $\begin{array}{l}\text { Longitudinal } \\
\text { Questionnaire for } \\
\text { environment } \\
\text { status and } \\
\text { existing data for } \\
\text { health status. }\end{array}$ & $\begin{array}{l}\text { Australia (New } \\
\text { South Wales); } \\
\mathrm{N}=36,224, \\
\text { Middle to older } \\
\text { age adults. }\end{array}$ & $\begin{array}{l}\text { Recreation } \\
\text { facilities, } \\
\text { footpaths, markets } \\
\text { within easy } \\
\text { walking distance } \\
\text { of one's home, } \\
\text { transport stop } \\
\text { within 10-15 min } \\
\text { walk from home, } \\
\text { and crime rate in } \\
\text { the } \\
\text { neighbourhood. }\end{array}$ & Self-reported & $\begin{array}{l}\text { There is a } \\
\text { significant } \\
\text { association } \\
\text { between perceived } \\
\text { crime rates and } \\
\text { neighbourhoods' } \\
\text { amenities and type } \\
2 \text { diabetes, due to } \\
\text { the impact on } \\
\text { public physical } \\
\text { activity during day } \\
\text { and night. }\end{array}$ & $\begin{array}{l}\text { Change the features } \\
\text { of residential } \\
\text { neighbourhoods to } \\
\text { enhance crime } \\
\text { prevention and } \\
\text { proximity to local } \\
\text { facilities in } \\
\text { collaboration with } \\
\text { crime prevention } \\
\text { agencies and urban } \\
\text { designers. }\end{array}$ \\
\hline $\begin{array}{l}\text { (Tewahade } \\
\text { et al., 2019) }\end{array}$ & $\begin{array}{l}\text { Longitudinal; } \\
\text { Used existing } \\
\text { data; Used } \\
\text { multistage } \\
\text { sampling. }\end{array}$ & $\begin{array}{l}\text { U.S. nation-wide; } \\
\mathrm{N}=2,785 \text {, } \\
\text { Adolescents and } \\
\text { emerging adults. }\end{array}$ & $\begin{array}{l}\text { Land-use mix, } \\
\text { street connectivity, } \\
\text { residence density, } \\
\text { park density, } \\
\text { recreational } \\
\text { density and } \\
\text { walkability. }\end{array}$ & Self-reported & $\begin{array}{l}\text { Participants who } \\
\text { live in a high land- } \\
\text { use diversity had } \\
\text { more active } \\
\text { transportation. } \\
\text { Higher residence } \\
\text { density is related to } \\
\text { active transport, } \\
\text { walkability, higher } \\
\text { densities of parks } \\
\text { and recreation area } \\
\text { had significantly } \\
\text { higher chance of } \\
\text { reporting active } \\
\text { transport. }\end{array}$ & $\begin{array}{l}\text { Built environment } \\
\text { characteristics need } \\
\text { to be addressed in } \\
\text { order to build } \\
\text { neighbourhoods with } \\
\text { higher range of } \\
\text { walkability and } \\
\text { liveability to increase } \\
\text { physical activity. }\end{array}$ \\
\hline $\begin{array}{l}\text { (Koohsari et } \\
\text { al., 2019) }\end{array}$ & Descriptive & - & $\begin{array}{l}\text { Street layouts and } \\
\text { connectivity. }\end{array}$ & $\begin{array}{l}\text { Natural } \\
\text { movement in } \\
\text { built } \\
\text { environment } \\
\text { using space } \\
\text { syntax method to } \\
\text { predict } \\
\text { pedestrian } \\
\text { movement. }\end{array}$ & $\begin{array}{l}\text { Using space syntax } \\
\text { in urban design can } \\
\text { help policy-makers } \\
\text { to predict the } \\
\text { people natural } \\
\text { movements and to } \\
\text { know where to } \\
\text { locate the } \\
\text { functional space or } \\
\text { other commercial } \\
\text { or residential land- } \\
\text { uses. }\end{array}$ & $\begin{array}{l}\text { Better to use space } \\
\text { syntax techniques to } \\
\text { apply urban planning } \\
\text { practices and } \\
\text { strategies which } \\
\text { motivate walking for } \\
\text { transport. }\end{array}$ \\
\hline
\end{tabular}




\section{Copyrights}

Copyright for this article is retained by the author(s), with first publication rights granted to the journal.

This is an open-access article distributed under the terms and conditions of the Creative Commons Attribution license (http://creativecommons.org/licenses/by/4.0/). 